\title{
Languages Without Borders: TESOL in a Transient World ${ }^{1}$
}

\section{Shondel Nero}

In today's transient world, where a continual multidirectional flow of people, goods, and services has deterritorialized languages and their users, languages, especially English, are now without borders. In this context, English language teaching (ELT) as a profession is called to a new task. In this article, I examine this task by asking the fundamental question: What does/should English-language teaching and learning look like in a world of languages without borders? I discuss the changing faces of English within and beyond the field of TESOL. I argue that the spread and natural evolution of English itself, combined with the transience in the population of English-language users, have forced a reexamination of the goals of English-language learning and teaching as well as a reconceptualization of the English language itself along with sacredly held paradigms in ELT.

Dans notre monde transitoire, où le flux multidirectionnel de gens, de biens et de services a déterritorialisé les langues et leurs locuteurs, les langues notamment l'anglais n'ont plus de frontières. Ce nouveau contexte oblige une réorientation au sein de la profession de l'enseignement de l'anglais. Dans cet article, j'étudie cette nouvelle direction en posant une question fondamentale: À quoi devrait ressembler l'enseignement et l'apprentissage de l'anglais dans un monde où les langues n'ont pas de frontières? J'évoque les nouveaux visages de l'anglais dans le domaine de TESOL (Teachers of English to Speakers of Other Languages) et au-delà de celui-ci. Je maintiens que l'extension et l'évolution naturelle de la langue elle-même, combinées à la nature transitoire de la population des usagers de l'anglais, nous obligent à reconsidérer tant les objectifs de l'enseignement et l'apprentissage de l'anglais que la langue anglaise elle-même et les paradigmes sacrés en enseignement de l'anglais.

When the professional organization Teachers of English to Speakers of Other Languages (TESOL) was founded in 1966, the world, at least linguistically speaking, was a different place. In a sense, we positioned languages within borders. We thought we knew then which countries were "English-speaking" or "Spanish-speaking" and which were not. We thought we knew who was a native speaker of English and who was not. Our views then were considered acceptable because they were filtered through the lens of a less transient world. Almost 30 years after the founding of the TESOL organization, Widdowson (1994), speaking before the annual convention of TESOL professionals, realizing the shifting linguistic tide, asked the then audacious question: 
"Who really owns English?" Widdowson's speech was made in the context of the burgeoning of Englishes around the world as a result of globalization, and population movement within and across borders. To put this in perspective, Graddol (2006) states, "between 1960 and 2000 the total number of international migrants had doubled to 175 million, representing nearly $3 \%$ of the world's population" (p. 28). Many of these migrants are multilinguals who among their languages use English as a lingua franca (ELF), thereby decentering the English language from what Kachru (1992) has referred to as the traditional "inner circle" English-speaking countries: Canada, the United States, the United Kingdom, Australia, and New Zealand. Today we are fully engaged in a transient world where a continual multidirectional flow of people (e.g., migrant workers, immigrants, asylum-seekers and refugees, tourists, business workers, international students, peacekeeping forces and troops, emergency aid and NGO workers, Graddol), goods, and services (e.g., customer service outsourcing) has deterritorialized languages and their users. What does this movement mean linguistically? Statistics Canada (www.statcan.gc.ca) shows that Canada accepted 247,200 immigrants in 2008. Anisef et al. (2010) note that these immigrants to Canada speak at least 150 languages, which filter into schools. Graddol's figures illustrate that since 2004, more than 230,000 Eastern Europeans have registered to work in the UK owing to free labor movement in the European Union, which has spawned new linguistic communities in small British towns. In terms of tourism, of the 763 million international travelers in 2004, "nearly three-quarters of visits involved visitors from a non-English-speaking country travelling to a non-English-speaking destination" (p. 29). Thus languages, especially English, are now without borders. In this context, TESOL as a profession is called to a new task. In this article I ask a fundamental question that faces the TESOL profession today: What does/can English-language teaching (ELT) and learning look like in a world of languages without borders? This is essentially a two-part question: the first part deals with ELT itself, and the second deals with language movement owing to the transience of the categories of people listed above and the implications of the latter for language definition, linguistic identities, language teaching and learning, and language research.

\section{A Snapshot of English in the 21st Century}

In order to address the first part of the above question, we need to examine the state of ELT itself. Who is learning English? For what purpose? Who is teaching it? In what contexts? What are the goals? How is proficiency in the language to be assessed? To grasp this issue fully, ELT needs to be situated in the broader context of what is happening with languages, especially English, worldwide, and so I address the second part of the question first.

Some sobering statistics underscore the importance of English in the world today. In Kachru's (1992) now famous three concentric circles of Eng- 
lish, he estimated in the last decade of the 20th century current users of English in the inner circle as 320-380 million; in the outer circle, 300-500 million; and in the expanding circle, 500-1,000 million. These were by all accounts conservative estimates. More recently, Crystal (2003) offered a fuller picture of English use worldwide.

- About one quarter of the world's population is fluent or competent in English (fluency and competence are relative terms here);

- In roughly 75 countries or territories English holds a special place as a primary, official, or second language (the inner and outer circles), from Canada and the US to Jamaica to Singapore to Zimbabwe to Australia.

- Approximately 329 million people are L1 English-speakers, a conservative estimate. If we add in Pidgin- and Creole-speakers, an additional 80 million brings the figure to just over 400 million.

- Another 430 million have learned English as an L2. Again, these figures must be taken with caution as estimates are not available for many countries.

- Add to this the expanding circle of approximately 750 million speakers.

- The grand total is somewhere in the vicinity of 1,500 million speakers of English, making it the most widely spoken language in the world.

Even more stunning are the projections for the next 50 years. Population growth in areas where English is an L2 is more than double that of where it is an L1. And according to Graddol (1997), the proportion of the world's population for whom English is an L1 will drop to about $5 \%$ by 2050. Add to this the immigration trends alluded to above where English L1 and L2 speakers will be moving across and shuttling between the solid lines of the three traditional circles in search of work and upward mobility. A revised Kachru (1992) model would need to include bidirectional arrows pointing across concentric circles of broken lines, indicating far greater numbers of projected transnational ELF users.

\section{Languages on the Move: Three Ways}

These statistics obviously have a long and complicated history. Crystal (2003), Graddol $(1997,2006)$, and other preeminent scholars of the globalization and future of English have already offered compelling analyses (from both history and demographics) of how English has come to be the global language it is today. We know that English did not become a world language by dint of any inherent superiority of the language. Scholars like Phillipson (1992), Canagarajah (1999), and Brutt-Griffler (2002) have persuasively made the case that major issues such as linguistic imperialism and resistance to linguistic imperialism have largely accounted for the historic spread of English worldwide and for its users to make the language their own. These issues have now evolved into what I see as three major ways by which languages have been moving beyond their traditional nation states or beyond relatively defined speech communities. The first is population 
movement in the form of internal migration and migration across countries and continents in search of labor, as noted above. The second is through technology via the Internet, e-mails, blogs, and so forth, which I discuss below. The third is through popular culture: music, film, television, art, and so forth. However, in recent years, it has been the combination of population movement and the Internet that has radically taken most of the major world languages, and especially English, across borders. In other words, many people are spreading, using, fashioning, and changing English to suit their needs beyond the confines of the traditional institutions of language-spread such as schools and churches.

\section{Technology}

Graddol (2006) points out that technology is changing the social, economic, and political structure of 21st-century societies. Voice-over Internet protocols such as Skype as well as text messaging are rapidly replacing traditional telephones. Skype had over 50 million users by 2005. Graddol forcefully debunks the myth of English-language dominance on the Internet. He emphasizes that whereas $51 \%$ of Internet users were English-speaking in 2000, this figure dropped to $32 \%$ by 2005 and continues to drop. He further argues that the Internet is now the communication tool of choice for multilinguals to link diasporic linguistic communities, and it includes growing numbers of Mandarin, Spanish, Hindi, and Arabic speakers. The number of major media outlets in languages other than English is also growing: Al Jazeera (Arabic) and Telesur (Spanish); however, in media, English is still the language of global reach, and so, for example, Al Jazeera launched an English-language television channel in 2006.

\section{Language Movement Creates New Challenges}

What are the consequences of radical language movement? We see that as language movement has simultaneously decentered and changed languages, the process has called into question the boundaries of languages, the linguistic identities of speakers, and the construct of the native speaker. This is not to suggest that English is the only language that transcends borders. A good number of educators have encountered in classrooms or elsewhere the Chinese-speaker born in Vancouver; the Spanish-speaker born in New York; the Hindi-speaker born in Sydney, Australia; or the Japanese speaker born in Peru: living proof that many of the major world languages have been transported far beyond the borders of their historic homelands. Moreover, ongoing immigration through professional and family sponsorship to Canada, the US, and other Western countries guarantees a continual flow of new immigrants who bring their home language(s) to the host country, even as less recent immigrants begin to assimilate and lose their heritage languages. But 
English is our best test case. No other modern language has seen its definition, ownership, and use more challenged by the movement of its speakers (native and nonnative) than the English language.

\section{Definition}

Defining what counts as English is tricky business. For example, there is a sense that if I use a phrase like je me souviens, everyone would agree that I was not speaking English, but when, as happened in New York, a female Jamaican patient told her US physician, "Me bruk me foot" (I broke my leg), he was somewhat puzzled by this phrase from a patient whom he thought was English-speaking and, more importantly, who considered herself English-speaking. The Creole English of this Jamaican woman called into question (for this physician at least) what counts as English. Yet in the context of the normal doctor-patient interaction coupled with a shared need for mutual understanding, no doubt the patient and her doctor did the necessary pragmatic work to understand each other. The rapidly growing number of immigrants from the English-speaking Caribbean like this Jamaican woman, who have brought their versions of English to Toronto and other major urban centers in Canada (www.statcan.gc.ca), the US, and elsewhere, has challenged our tendency to have a unitary view of English. So too have other immigrants from Asia, Africa, Europe, and Latin America who have been transporting their varieties and/or use of English across borders, giving renewed dynamism and vitality to the language. McArthur (1998) tries to capture this complex phenomenon of a perceived unitary model of English coexisting with multiple varieties of English (what he calls the English languages). He suggests that it is a paradox not only true of English, but of all languages, that is, "they are monolithic and multiple at the same time" (p. 201).

\section{Ownership}

Since Widdowson's (1994) challenge to the TESOL profession to rethink the ownership of English because of its worldwide spread, the language has acquired millions of new "owners" worldwide. However, language ownership is complicated. It is an unsigned contract that allows speakers to have a claim to or perception of ownership based on self-ascribed or socially ascribed phenomena that are not necessarily tangible (e.g., identity construction, practical need to be understood, actual proficiency). It is what allows the child born in Canada of two English-speaking parents to claim ownership or to be a native speaker of the language (self-ascribed family linguistic identity). It is what allows the Malay-speaker to communicate with the Japanese-speaker in English (taking ownership of a lingua franca). It is what allows the fluently bilingual (Spanish/English) Latina to deliver her paper in English to an au- 
dience that understands her (actual proficiency). Finally, it is the unsigned contract that allows speakers to move languages across countries and continents and to adapt them to their new environment.

\section{Use}

This leads to the question of use. Crystal's (2003) figures on the growth of English L2-speakers mentioned above might give the impression that the language is out of control and at risk of disintegrating into separate, mutually unintelligible languages. Yet Crystal notes that this is not the case. Fortunately, language has a wonderful way of self-regulating. Crystal argues that it is the need for intelligibility that forces the users of Englishes around the world to converge toward a mutually understandable variety a kind of international standard for formal and international communication. Conversely, an insightful body of research on language and identity (Block, 2007; Pavlenko \& Blackledge, 2004; Toohey, 2000), and especially Norton's (1995, $1997,2000)$ seminal work on identity as a site of struggle (along with her concept of investment to understand the complex relationship between the language learner and the target language) explains why English-speakers assert their own idiolect or locally or regionally accepted norms of speech for communication in and across all the spheres of English: inner, outer, and expanding circles. It is this creative tension between intelligibility and identity that maintains the dynamism of the language.

\section{Implications for TESOL}

Given the complexity of definition, ownership, and use of English, what are the implications for TESOL as a profession? This takes me back to the question What does/can English-language teaching and learning look like in a world of languages without borders? First, who is learning English(es) and who is teaching it (them)? We know that English-learners run the gamut from kindergarten to adult, from immigrant to refugee, from the not well-schooled to the highly educated. They are learning English informally from peers, on the streets, in the marketplace, from the Internet, from television, radio, and so forth. We know that teachers of English-learners run the gamut too; that most of them are teaching in contexts where English is not the dominant language; that if they teach in contexts where English is the dominant language such as Canada, the US, or the UK, and especially in public schools, their ESL class might change daily as new immigrants keep coming, bringing their languages and varieties of English with them. Or more to the point, their classes may have no immigrants at all, but many children of immigrants born in the host country who speak a language other than English at home. Many teachers, especially in large urban centers, have had such children in their classes (Anisef et al., 2010). 
There are also many reasons for learning English, depending on whether one is living in an English-dominant country. For immigrants in a new English-dominant environment, these might include: children or adults learning English for success in school or business, or for survival in the new environment, including gaining employment. In non-English-dominant countries, the reasons might include: to communicate with multilinguals from other ethnic/linguistic groups who do not share the same language; to prepare for migration to, or to study in, an English-dominant country; or to conduct business with someone from another country. This range of reasons for learning the language should guide the goals of ELT. For too long the field of TESOL has been frozen on the elusive native-speaker of English standard as the goal for ELT. As Kachru (2006) and others have noted, the concept of a native speaker of English is essentially an abstraction. There is no reason why the goal of teaching English to a Japanese student who wants to pass the high school English exam to get into a Japanese university should be the same as that of a foreign student who must pass the Canadian Academic English Language (CAEL) assessment in order to gain entry into a Canadian college. Just as the goals of English-learning of each of these two learners are decidedly different, so too should be the goals of Englishteaching. In other words, a blanket so-called native-speaker target is neither practical nor relevant for every learner or in every context. Scholars of world Englishes such as Canagarajah (1999), Kachru (1996), and Kachru and Nelson (2006) have steadfastly decried purely exonormative ${ }^{2}$ teaching goals and language standards in outer- and expanding-circle countries, which have been the dominant paradigm for a long time, arguing instead that ELT goals should more accurately reflect the diverse needs and goals of the learners. If this were the case, then nativized English pronunciation, grammar, and lexicon should be accepted for learners who plan to remain in the outer and expanding circles. As EIL scholars such as Jenkins (2000) and Kirkpatrick (2007) have argued, most English-language learners (ELLs) will never live or work in an English-dominant country; hence they should not be required to strive for inner-circle proficiency. In Canada, the US, the UK, and other countries where English is dominant, it must be recognized that English in these countries is changing too, not only by the natural evolution of language, but also by the influx and influence of immigrant speakers of other Englishes and of speakers of languages other than English. For example, Toronto and New York respectively are homes to the largest number of Caribbean English-speakers outside the Caribbean: Toronto has just over 280,000 Caribbean immigrants, representing $6 \%$ of that city's population (www.statcan.gc.ca), and New York has approximately 600,000, representing $20 \%$ of the foreign-born population (New York City Department of City Planning, 2004). 


\section{What Can TESOL Do?}

Given these linguistic realities, what can TESOL do? I propose here some key areas that can be addressed to move the profession forward.

- Change of attitude in and beyond school; tolerance for linguistic diversity;

- Language policy/planning;

- Teacher-training and ELT goals;

- Assessment and high-stakes testing;

- Technology and language;

- Research; new paradigms.

\section{Attitudes}

Any hope for change in language-teaching must begin with a change in language attitudes in and beyond school given that linguistic diversity will continue to be the reality of the 21st century. This means a concerted effort to face our own prejudices in and beyond the classroom. As Cliett (2003) argues, "English teachers have the opportunity to expand on new pedagogies in the face of the changing global landscape. The first frontier of global expansion is negative attitudes toward languages other than English and varieties other than the standard" (p. 67). Jenkins' (2007) work underscores these attitudes by noting how both teachers and learners privilege "correct" native-speaker varieties of English and routinely show biases against the English of nonnative speakers. Language teachers must face these attitudes by asking honest questions: Why are we teaching English? What are our goals for our students in our particular teaching contexts? How do we view the English language(s)? How do we view speakers of nonstandard and/or non-Canadian varieties of English? How do we view languages other than English and their speakers? Answers to these questions might begin to reveal our core attitudes and beliefs about languages and their speakers, and this might be a good starting point for reexamining language attitudes.

\section{Language Policy and Planning}

With linguistic diversity as a given, language policy and planning would need to proceed from a pluralistic stance. In Canada, the US, and other English-dominant countries, this means challenging a monolingual assimilationist stance, which gave rise, for example, to the English-Only movement and the dismantling of bilingual education in the US. What is needed is a language policy that is additive, that adds a new variety of English to the students' existing linguistic repertoire rather than forcing a false choice between home and school language. Countries like South Africa have taken a more progressive approach by adopting an English Plus language policy in recognition of the rich, multilingual context there (Webb, 2003). 


\section{Teacher Training and ELT Goals}

Not so long ago, the typical TESOL graduate program, especially in inner-circle countries, consisted of a menu of courses in ESL methods, second-language acquisition (SLA), linguistics, structure of English, assessment, and for those seeking certification to teach at the K-12 levels, content-based instruction (CBI). The premise of many of these programs was of a fixed English with a fixed grammar to be taught to clearly defined nonnative speakers by prepackaged methods (e.g., Silent Way, Communicative Language Teaching, CBI, etc.). But in the last 20 years, this premise has been challenged. English has diversified and changed, world Englishes have emerged, and many people from outside the inner circle now consider themselves native speakers of English. Furthermore, several of the teaching methods mentioned above have been questioned as to their relevance to international contexts. So it seems that we need another kind of teacher training, one more attuned to the diverse linguistic reality of the 21st century, less prescriptive, and with more contextspecific goals. TESOL programs should, therefore, require courses in sociolinguistics and world Englishes for preservice and inservice teachers, challenging them to rethink concepts of standard English, correct versus incorrect grammar or usage, and native versus nonnative speaker. Many TESOL programs have begun to do this, but much more needs to be done. For example, linguistic diversity training should extend to all teachers of English, not only ESL teachers, and should address the diversity in English more directly. In addition, exposing teachers to the language and culture of their students through study-abroad programs offers a real opportunity for teachers to live and learn language and cultural diversity in more authentically.

\section{Assessment}

One area where ESL teachers truly feel the effect of language diversity is in assessment. In the outer and expanding circle countries, the question of whether to assess students on exonormative or endonormative standards is still a challenge. Although some scholars have called for movement away from a disproportionate focus on exonormative standards (Kachru, 2006), the bidirectional movement of people and language across countries in the various circles does not allow standards of assessment to be neatly compartmentalized as generically exonormative or endonormative. Rather, it might be more helpful to assess language-learners according to the context and goals. Learners in the outer and expanding circles who wish to study in English-dominant countries abroad may be assessed on a more international standard than those using English for local interaction. This international standard for assessment is already evident in tests such as TOEFL, TOEIC, and IELTS. Although TOEFL test-makers have made a concerted effort to make the test more congruent with the actual academic writing demands of 
inner-circle universities, the debate about which standards to employ in these tests continues. Recent empirical work by Hamp-Lyons and Davies (2008) sheds light on the tension between which variety of English should be privileged in these tests: international English (IE), seen as more Western and recognizing only the educated inner-circle speaker, or world Englishes (WE), which values the Englishes of all users of the language. In the inner-circle countries such as Canada, the US, and the UK, assessment in school settings has historically been focused on prescriptivist academic language conventions. Nowhere is this more prevalent than in the disproportionate focus on standardized testing, which puts an undue burden on both language-learners and teachers to prepare for assessment based on a narrowly defined version of standardized English. Menken's (2008) work captures the challenges faced by ELLs in meeting the linguistic demands of standardized tests. Frontline teachers may have limited time, resources, and power to fight the culture of standardized testing, but TESOL as an organization can certainly lobby Educational Testing Service to change standardized tests to make them more responsive to current linguistic realities. Meanwhile, teachers can move beyond simply teaching to the test by designing classroom assignments and formative assessment that allow room for students to draw on their diverse linguistic repertoire, for example, writing dialogue and role-playing; reading and writing about literature written in diverse varieties of English; multiple opportunities for low-stakes writing; allowing the use of code switching, and so forth.

\section{Technology and Language}

Technology as a teaching tool for language has been in place for some time now with such methods as Computer Assisted Language Learning (CALL), but the widespread use of the Internet, including texting, e-mails, search engines, and so forth, provides fertile ground for language teaching and learning. Online writing and texting have spawned new hybrid genres (a cross between speech and writing) that can be explored and taught in the context of language change. As mentioned above, given that most Internet users are multilingual, teachers can harness their linguistic repertoire to raise awareness of bi/multilingualism, bi/multidialectalism, bi/multiculturalism, and world Englishes; teach intercultural pragmatics online; and do translation activities.

\section{Research}

The challenge of designing appropriate assessment in the complex and transient linguistic landscape of the 21st century is but one area of fertile ground for research. However, as English continues to spread and change, and as its users increase, move, and diversify, opportunities are presented for researchers to problematize and rethink a number of other fundamental con- 
cepts such as: (a) native/nonnative speaker (immigrants shuttling between home countries and new home countries complicate native speakership, linguistic identities, and language use); (b) the traditional definition of what counts as English in general and standard English in particular; (c) other traditional SLA concepts such as interlanguage, fossilization, error, pragmatic failure, ESP-propelled genre analysis (Kachru, 2006), in the light of world Englishes; (d) language-crossing and language-borrowing, as immigrant groups live side by side and interact with one another (Ogulnick, 2000; Rampton, 1995); (e) the concept of the inner/outer/expanding circles, as population transience continues; (f) how technology and the Internet have already begun and will continue to challenge traditional ways of thinking about spoken and written language and also audience; and (g) content and standards used in developing materials.

\section{Conclusion}

The rapid and remarkable shifts in the linguistic tide worldwide over the last quarter of a century have challenged English-language learning and teaching in unprecedented ways. The spread and natural evolution of English itself, combined with the transience in the population of English-language users, have forced reexamination of the goals of English-language learning and teaching, as well as a reconceptualization of the English language itself along with sacredly held paradigms in ELT. These changes are likely to continue and to evolve throughout the 21st century, and they will require conceptual and practical flexibility in advancing the field of ELT.

\section{Notes}

${ }^{1}$ This article is adapted from a plenary speech delivered at the TESOL Convention in New York City in 2008.

${ }^{2}$ Exonormative means that the language variety relies on norms from outside the local community, for example, outer- and expanding-circle countries basing their language assessment on innercircle norms. Endonormative, by contrast, means the language variety is normed on local standards from within the speech community.

\section{The Author}

Shondel Nero is an associate professor of TESOL at New York University. Her research focuses on the education of ESL and standard English-as-a-second-dialect speakers, especially speakers of Caribbean Creole English. She has written two books and numerous articles on speakers of Caribbean Creole English and other world Englishes.

\section{References}

Anisef, P., Brown, R., Phythian, K., Sweet, R., \& Walters, D. (2010). Early school leaving among immigrants in Toronto secondary schools. Canadian Review of Sociology, 47(2), 103-128.

Block, D. (2007). Second language identities. London/New York: Continuum.

Brutt-Griffler, J. (2002). World English: A study of its development. Clevedon, UK: Multilingual Matters. 
Canagarajah, A.S. (1999). Resisting linguistic imperialism in English teaching. Oxford, UK: Oxford University Press.

Cliett, V. (2003). The expanding frontier of World Englishes: A new perspective for teachers of English. In G. Smitherman \& V. Villanueva (Eds.), Language diversity in the classroom: From intention to practice (pp. 67-75). Carbondale, IL: Southern Illinois University Press.

Crystal, D. (2003). English as a global language (2nd ed.). Cambridge, UK: Cambridge University Press.

Graddol, D. (1997). The future of English? London: British Council.

Graddol, D. (2006). English next: Why global English may mean the end of English as a foreign language. London: British Council.

Hamp-Lyons, L., \& Davies, A. (2008). The Englishes of English tests: Bias revisited. World Englishes, 27(1), 26-39.

Jenkins, J. (2000). The phonology of English as an international language. Oxford, UK: Oxford University Press.

Jenkins, J. (2007). English as a lingua franca: Attitude and identity. New York: Oxford University Press.

Kachru, B.B. (Ed.). (1992). The other tongue: English across cultures (2nd ed.). Urbana, IL: University of Illinois Press.

Kachru, B.B. (1996). The paradigms of marginality. World Englishes, 15, 241-255.

Kachru, Y. (2006). World Englishes and language education. In S. Nero (Ed.), Dialects, Englishes, creoles, and education (pp. 19-37). Mahwah, NJ: Erlbaum.

Kachru, Y., \& Nelson, C. (2006). World Englishes in Asian Contexts. Hong Kong: Hong Kong University Press.

Kirkpatrick, A. (2007). World Englishes: Implications for international communication and English language teaching. Cambridge, UK: Cambridge University Press.

McArthur, T. (1998). The English languages. Cambridge, UK: Cambridge University Press.

Menken, K. (2008). English learners left behind: Standardized testing as language policy. Clevedon, UK: Multilingual Matters.

New York City Department of City Planning. (2004). The newest New Yorkers 2000: Immigrant New York in the new millennium. New York: Author.

Norton Peirce, B. (1995). Social identity, investment, and language learning. TESOL Quarterly, 29, 9-31.

Norton, B. (1997). Language, identity, and the ownership of English. TESOL Quarterly, 31, 409-429.

Norton, B. (2000). Identity and language learning: Gender, ethnicity, and educational change. Harlow, UK: Longman/Pearson.

Ogulnick, K. (2000). Language crossings: Negotiating the self in a multicultural world. New York: Teachers College Press.

Pavlenko, A., \& Blackledge, A. (Eds.). (2004). Negotiation of identities in multilingual contexts. Clevedon, UK: Multilingual Matters.

Phillipson, R. (1992). Linguistic imperialism. Oxford, UK: Oxford University Press.

Rampton, B. (1995). Crossing: Language and ethnicity among adolescents. London: Longman.

Toohey, K. (2000). Learning English at school: Identity, social relations and classroom practice.

Cleveland, UK: Multilingual Matters.

Webb, V.N. (2003). Language policy in post-Apartheid South Africa. In J. Tollefson \& B.M. Tsui (Eds.), Medium of instruction policies: Which agenda? Whose agenda? (pp. 217-240). Mahwah, NJ: Erlbaum.

Widdowson, H.G. (1994). The ownership of English. TESOL Quarterly, 28, 377-392. 